\title{
Tahfizh Al-Qur'an Learning Management Model in Early Children in Family Education: A Study in Serang City, Indonesia
}

\author{
R. Renny Pudjiati ${ }^{1 *}$, Masyitoh ${ }^{1}$, Gofur Ahmad ${ }^{1}$, Diah Mutiara ${ }^{1}$
}

${ }^{1}$ Muhammadiyah University of Jakarta, Jl. K.H. Ahmad Dahlan, Cireundeu, Kec. Ciputat Tim., Kota Tangerang Selatan, Banten 15419 , Indonesia

\author{
DOI: $10.36348 /$ shhss.2022.v07i01.003 \\ | Received: 04.12.2021 | Accepted: 06.01.2022 | Published: 08.01.2022 \\ *Corresponding author: R. Renny Pudjiati \\ Muhammadiyah University of Jakarta, Jl. K.H. Ahmad Dahlan, Cireundeu, Kec. Ciputat Tim., Kota Tangerang Selatan, Banten 15419, \\ Indonesia
}

\section{Abstract}

Tahfizh Al-Qur'an for early childhood has received attention from Muslim families in Serang City, Banten Province. The research focus is on the tahfizh learning management model for early childhood. This study uses a qualitative analysis approach. Collecting data, through interviews, literature study, direct observation, and focus group discussions (FGD). The results showed that Muslim families in Serang City wanted to introduce the Qur'an to children from an early age before entering formal education at school. Families want their children to be pious and noble. Community leaders, academics, and politicians view the phenomenon of learning tahfizh Al-Qur'an as needing to get the support of the Serang City Government, through the issuance of regional regulations (perda) on tahfizh Al-Quran. Researchers found two novelties in this study. First, that the grouping of early childhood from 0 years to 3 years and from 3 years to 6 years was found to be better and more effective for the absorption of tahfizh Al-Qur'an. The grouping of these two age categories is very possible equipped with memorizing daily prayers as well as learning to recognize and write the letters of the Qur'an. Second, pregnant women are prioritized to memorize the Qur'an from the beginning of pregnancy until delivery. Then, after the birth, the mother introduced tahfizh Al-Qur'an to her child from the age of 0 years as an effort to generate auditory stimulation to make it easier to memorize the Qur'an. Learning Tahfizh Al-Qur'an from an early age is also a preparation for the formation of pious and noble children.

Keywords: tahfizh learning management, early childhood, family education.

Copyright ( ) 2022 The Author(s): This is an open-access article distributed under the terms of the Creative Commons Attribution 4.0 International License (CC BY-NC 4.0) which permits unrestricted use, distribution, and reproduction in any medium for non-commercial use provided the original author and source are credited.

\section{INTRODUCTION}

Early childhood education is a concern for parents. They realize that their children must be educated from an early age at home, before being educated at school. The family environment, school environment, and the wider community will help shape the character, morals, and habits of children. Therefore, for parents, education is the first and foremost thing. All of that must start from home education in the form of informal education.

The first and foremost education for Muslim families is religious education, including faith, worship, and morals. Parents have their own way of introducing faith, worship, and morals to their children. Early childhood, from 0 years to 6 years, is like a piece of white paper. Parents can write any color on the white paper. The wishes, ideals, and ambitions of parents are often reflected in their children. About children, advice Al-Ghazaly (Ulwan, 2015: 115)

"Children are a trust for both parents. Her pure heart is a precious gem. If he is accustomed to doing good, he will grow well and be happy in this world and the hereafter. However, if he is accustomed to doing bad things and left like an animal, he will be harmed and perish. How to take care of children with $t a^{\prime} d i b$, tahdib and ta'lim towards good morals "

Parents in Serang City prioritize tahfizh AlQur'an education for their children from an early age. In fact, tahfizh Al-Qur'an begins when pregnant women. When they give birth, pregnant women directly become tahfizh Al-Qur'an teachers for their newly born children. Parents prioritize learning tahfizh Al-Qur'an as 
R. Renny Pudjiati et al; Saudi J. Humanities Soc Sci, Jan, 2022; 7(1): 14-20

an effort to introduce religious teachings from an early age. The Holy Qur'an is the first and foremost lesson and education for children.

There are Tahfizh Al-Qur'an which are managed formally, specifically for tahfizh schools, some are managed non-formally, such as in salafy Islamic boarding schools, and there are also Tahfizh AlQur'an which take place informally in the environment family.

Tahfizh Al-Qur'an for early childhood needs to be cultivated, used as the basis for children's education, especially in Serang City. Before entering formal education, children need to be provided with education at home by their parents. The best education for children is tahfizh Al-Qur'an. Other education, such as memorizing daily prayers, can be a complement to the tahfizfh of the Qur'an.

The results of this study are also expected to be able to enrich the scientific treasures in theory and practice of learning tahfizh Al-Qur'an among early childhood, especially in Serang City.

\section{THEORY AND METHODOLOGY}

\section{A. Descending the Qur'an and Tahfizh Al-Qur'an Institutions}

The Qur'an was revealed regularly, in Mecca and in Medina, for approximately 23 years, 2 months and 22 days (Al-Hamidy, 1957:55). Prophet Muhammad Shollohu'alaihiwassalam ordered his companions to record the Qur'an. Prophet Muhammad Shollohu'alaihiwassalam, the recorders of the Qur'an, and the companions memorized the Qur'an. At that time, memorization, including memorizing the Qur'an, became a strong tradition. At that time, the tradition of memorizing was stronger than the tradition of taking notes or writing.

(Rokim, 2020: 59-62) mentions four developments in Al-Qur'an education. First, at the beginning of the revelation of the Qur'an which the Prophet Muhammad received directly from Allah Subhanahuwata'ala through the angel Gabriel. The second period, the Prophet Muhammad Sholallohu'alaihiwassalam taught the Qur'an to 70 of his companions, among others, Abu Bakr, Umar bin Khattab, Usman bin Affan, and Ali bin Abi Talib. In the third period, the young companions of the Prophet Muhammad Sholallohu'alaihiwassalam studied with the companions who were taught by the Prophet Muhammad, such as Usman bin Affan and Ubay bin Ka'ab. The fourth period, the era of bookkeeping reading the Qur'an. In this era there are the so-called seven readings of the Qur'an. (Al-Ma'sharawy and AlBakary, tt: 3-32) recorded 10 reading history. The first person to record reading Al-Qur'an (Rokim, 2020: 62), including Yahya bin Ya'mar (died $90 \mathrm{H}$ ). There is also a mention of Abu Hatim Al-Sijistany (died 225).

Still in (Rokim, 2020: 63-64), Nabil alu Ismail divides the education of the Qur'an into four parts or a kind of center for the study of the Qur'an. First, Madrasah Hijaz. These madrasas include the Holy City of Makkah and the Holy City of Medina, Riyadh, Qatar, Bahrain, and others. Second. Iraqi Madrasas. This madrasa includes Basra, Kufa, and others. Famous teachers here include Ibn Mas'ud, Ali bin Abu Talib, Abu Musa Al-As'ary, and others. Third. Sham Madrasa. These madrasas include Palestine, Jordan, Syria and Lebanon. The famous teacher here is Abu Darda. After the noon prayer in congregation in the mosque, Abu Darda formed groups for reading and memorizing the Qur'an. Fourth. Egyptian Madrasa. Islam was brought to Egypt by Amr bin Ash, a famous warlord, who later became the governor of Egypt. Amr bin Ash became the main teacher with Uqbah bin Amir, Abu Dharr, and Abdullah bin Abbas.

(Rokim, 2020: 66-71) recorded eight names of Al-Qur'an tahfizh institutions, namely (1) Al-Maqra in the Hijaz area, covering Mecca and Medina, and others), (2) Al-Khalawy in Sudan. (Khalawy itself comes from the word khalwat, meaning to be alone, meaning being alone to memorize the Qur'an), (3) AdDaksy (in Somalia. Daksi means a warm place to keep cold and heat out. Daksi is also meant to be a place to keep people from stupidity) in reading and writing the Qur'an), (4) Al-Maseed (in Sudan. A place set up for tahfizh Al-Qur'an, worship, and dormitory), (5) ArRibath (in South Yemen. One of the meanings of ribath is staying in the mosque. Ribath is also meant a scientific boarding school in Yemen), (6) Az-Zawiyah (meaning, corner or corner. Zawiyah is also defined as a place on the edge of the mosque or the veranda of the mosque), (7) Al -Mahdlarah (in Muritania. The name of a traditional educational institution. There are several lessons in this traditional educational institution, specifically sharia sciences), (8) Islamic boarding schools (in Indonesia. There are also Islamic boarding schools specifically for tahfizh Al-Qur'an Generally, Islamic boarding schools are places to study Islamic sciences).

\section{B. Early Childhood Education Management}

(Mulyasa, 2012: 20) Defines management as everything related to the management of the process to achieve the goals set, both short-term, medium-term and long-term goals. Educational administration experts (Sergiovanni, Coombs, and Thurson, 1980:67) define management as "a process of working with and through others to accomplish organizational goals efficiently".

In Arabic, management is defined as idaarah, which comes from the word adaara, which means to regulate. (Ramayulis, 2008: 362) states that the same 
R. Renny Pudjiati et al; Saudi J. Humanities Soc Sci, Jan, 2022; 7(1): 14-20

understanding with the nature of management is altadbir. This word is a derivation of the word dabbara (to regulate) which is widely found in the Qur'an. Allah Subhanahuwata'ala has a family from among humans. "The companions asked, "O Messenger of Allah, who are they?" He replied, "The people of the Qur'an are the family of Allah and those close to Him. (HR Ahmad).

The phases of growth and development of children in Islamic family education have been given guidance in the Qur'an and Al-Hadith, so that parents can utilize and carry out educating children according to the nature of the child.

According to the basic theory of child development and psychology, it is stated that the growth of children's intelligence at the age of 0 years to the age of 6 years is called the golden age or "golden age".

The results showed that with children's brain development reaching the age of $0-4$ years, it had reached $50 \%$, up to 8 years it was $80 \%$, and until the age of 18 years it was $100 \%$.

\section{Relevant Research Results}

There are seven scientific papers studied by the researcher. First, Syaeful Rokim. Acceleration of Tahfizh Learning at Al-Qur'an Educational Institutions, (Study at the Second Wadi Mubarak Islamic Boarding School, Bogor, Farid Wajdi: "Tahfizh Al-Qur'an in the Study of 'Ulum Al-Qur'an; Study of Various Tahfizh Methods".

Third, Bahrun Ali Murtopo examines Islamic Education Management: Parental Management of Children. Fourth, Bobi Erno Rusadi, "Implementation of Tahfizh Al-Qur'an Learning for Students at the Nurul Quran Islamic Boarding School, South Tangerang".

Fifth, Mufatihatut Taubah examines "Children's Education in the Family with an Islamic Perspective". Sixth, Nurdini Bismi Fitria with the title "Implementation of Tahfizh Al-Qur'an Learning in Early Childhood at Mutiara Qurani Kindergarten Bantul". Seventh Abdul Hamid. Management of Tahfizh Al-Qur'an Learning at Islamic Boarding Schools in Lampung Province

From some of the results of the research above, what distinguishes this research is that this research focuses on the importance of the tahfizh AlQur'an learning management model in family education starting from planning, implementation, evaluation, and results in a household structure or family with children early age.

\section{Place, Time, and Object of Research}

Serang City is the capital city of Banten Province, which was a division of Serang Regency in 2007. Its presence is a logical consequence of the existence of Banten Province. Serang City was inaugurated on November 2, 2007 based on Regional Regulation Law no. 32 of 2007. (Biro Kesra, Provinsi Banten 2018). The time of the study was carried out from December 2019 to June 2021. The object of the research was 17 families with children aged 0 to 6 years. The object of this research to 17 tahfizh families is considered to represent the existence of families in Serang City because they are spread over at least 4 subdistricts out of 6 sub-districts in Serang City.

\section{E. Data Collection and Data Analysis}

Data were taken directly from 17 families as informants who live in the city of Serang. Primary data sources are the results of interviews with parents, teachers, students (early children), educational leaders, and representatives from the government, namely members of the House of Representatives (DPRD).

Data collection is done through (a) observation. This study uses participatory observation, namely the researcher is involved in the activities of the subject being taken, (b) interviews. Interviews in this study were conducted in a structured manner, namely the researchers conducted structured interviews with parents who held tahfizh Al-Qur'an for their children at home, (c) focus group discussions. In an effort to enrich the findings to strengthen the findings, the researchers conducted discussions, namely focus group discussions with educational leaders and parents of early childhood children, as an effort to re-examine the results of the research, (d) literature study. Researchers read books that are relevant to early childhood education and tahfizh Al-Qur'an. Literature study was taken to provide enrichment and sharpening of analysis in interpreting data, (e) documentation. Documentation technique is one way of collecting secondary data. This is done by recording, copying or recording directly data related to activities in family education.

The analysis model used by the researcher is the Miles \& Huberman model, as described by Sugiyono, that activities in qualitative data analysis are carried out interactively and continuously through the stages: (1) data reduction (data reduction); (2) data presentation (data display); and (3) conclusions (Sugiyono, 2012: 131).

\section{RESEARCH RESULTS AND DISCUSSION}

Serang City is the capital city of Banten Province which is a division of Serang Regency in 2007. Its presence is a logical consequence of the existence of Banten Province. Serang City was inaugurated on November 2, 2007 based on Regional Regulation Number 32 of 2007. (Biro Kesra, Provinsi 
R. Renny Pudjiati et al; Saudi J. Humanities Soc Sci, Jan, 2022; 7(1): 14-20

Banten, 2018). Serang City, years by years, experienced dynamic developments in all fields, including education, economy, trade, and services.

The population of Serang city is $6,92,101$ people, consisting of 353,971 men and 338,130 women. The number of early childhood children (1-5 years), as many as men: 33,748 children and women 32,167 people Religion of the population consists of Islam $89.23 \%$, Christian 3.77\%, Catholic $4.84 \%$, Buddhist $1.89 \%$, Hindu $0.23 \%$, and Kong Hu Chu $0.04 \%$. (BPS Serang City, 2021).

Based on the observations of researchers in the field, many families hold tahfizh at their homes. This condition automatically grows a new community, namely the Al-Qur'an tahfizh family community.

Faih Hudan's family said that the main goal or vision in life is to introduce the pillars of faith and love for Allah Subhanahuwata'ala, Prophet Muhammad Shollohu'alaihiwassalam, and Islam. Akhmad Nasrullah's family has the same goal and vision of life. Believing in Allah Subhanahuwata'ala and His messenger is the most important thing.

The Ferdiansyah family sets the main goal of family education, which is to enable children to learn to read, write, and memorize the Qur'an. Love for the Qur'an is absolute. Zamzam Riyadhi sets a vision on the development of three domains, namely motor development, mental stability, and children's spirituality.

Rifqi Firdaus' family has set a vision for their children's education so that they can fortify themselves from the negative effects of globalization. Syafrijal Sabon has a view in the education of his children so that they can learn from an early age and learn to socialize with peers and their environment.

Why do parents set a vision for education? Faih Hudan is well aware that a strong faith is the foundation to face and respond to life. Tb. Lutfi Rahman reasoned that the basic nature of children from the age of 0 years to the age of 7 years is the power to absorb whatever is given by the environment. Khairul Ridwan's family wants to prepare their children for good education and at the same time increase their intelligence optimally.

Ferdiansyah reasoned for the provision of good deeds of both parents. Al-Qur'an as a guide for life. The Qur'an educates children to be pious (saleh, in Arabic langage. It means the very good boy). Faih Hudan's family said that apart from their children studying at Homeschooling Rabbaya every morning and evening, they also teach reading and memorizing at home after sunset. Rifqi Firdaus' family holds tahsin and tahfizh Al-Quran regularly after the Maghrib prayer in particular. Syafrijal Sabon takes advantage of the time after sunset to instill basic education from an early age.

The planning was carried out by Irham Indallah's family starting with reading prayers and short letters before going to bed. Ulfi practices it by generating confidence in the child's abilities. The Ganang Pamungkas family plays at home while listening to the Qur'an.

Asep Saepuddin's family does this by giving habituation since childhood. The habit of praying before or after doing anything, teaching prayer, reading the Qur'an, and setting an example of noble character. Ibrahim Aryadi listened to the reading of the holy Qur'an for his children since childhood.

Tb family. Machfudz planned education since in the womb by providing good nutrition. Iwan Sofwan's family provides good nutrition to mothers and routinely checks health so that children are born healthy and normal. Khairul Ridwan is of the view that every baby who is still in the womb has a strong bond with his mother. Therefore, the mother's attitude or actions will indirectly have an impact on the baby.

The plan to grow children's love for the Qur'an was carried out by Faih Hudan through stories taken from the Qur'an. Tb. Lutfi Rohman plans for children to love the Qur'an by listening to and reading the Qur'an frequently. Akhmad Nasrullah by cultivating a love for the strains of the holy verses of the Al-Qur'an in front of the children. Tb. Machfudz gave an example of reciting the Al-Qur'an in front of children and introducing the Qur'an verbally before introducing the letters. Meanwhile, Zamzam Riyadhi teaches the AlQur'an in a certain way and target, "We plan to achieve a certain target, but according to the age and ability of the child. Families guide children. Iwan Sofwan's family constantly invites their children to read the Qur'an.

Khairul Ridwan conducts education that helps, reminds, and advises in performing daily worship, both obligatory and voluntary. Telling the history that is in the Qur'an is the first way to love the Qur'an. Irman Mukhtar made the habit of reading the Qur'an together after the Maghrib prayer.

Lutfi Ardiansyah listens to the reading of the Qur'an and tells the greatness of the Qur'an in a language that is easily understood by children. According to Rifqi Firdaus' family, parents should always read the Qur'an as often as possible. Syafrijal Sabon plans for children to love the Qur'an since the child is in the womb. According to Ferdiansyah's family, the practice of praying, fasting and alms can be done from an early age. Said Irman Mukhtar's family, 
R. Renny Pudjiati et al; Saudi J. Humanities Soc Sci, Jan, 2022; 7(1): 14-20

"We apply it in daily activities such as reading prayers before and after waking up, at mealtimes, on trips, and teaching the 5 daily prayers". Lutfi Ardiansyah's family often invites their children to worship together.

For other families, such as the Ferdiansyah family, tahfizh Al-Qur'an is carried out in stages, from the age of 2 years to the age of 6 years. Irman Mukhtar's family taught their son at the age of 2 years. Lutfi Ardiansyah's family teaches the Qur'an to children from the age of 3 years. At that age, children have begun to be directed or invited to tahfizh. Irham Indalloh's family sent their son to school when he was 3 years old. This child is now starting to memorize the Qur'an. Ulfi's family did the same.

For the Tb. family. Machfudz, the target is that children are expected to be able to memorize short letters with perfect readings. Also Iwan Sofwan's family, it is hoped that children can read the Qur'an well with its translation, and Irman Mukhtar's family, children can memorize short letters so they can be used for prayer. According to the family of Khairul Ridwan, after a child has memorized the Qur'an, it will be easy to understand its contents. Ferdiansyah family hope, older children can teach younger siblings who have not memorized the Qur'an. Lutfi Ardiansyah's family expects his son to become $a$ hafizh of the Qur'an. Ulfi's target is that the child becomes a good person. Ibrahim Riyadi's family wanted his son to be loved by Allah.

Planning so that children memorize the Qur'an is carried out by Faih Hudan's family. Parents recite the verses of the Qur'an every day so that it automatically enters the child's brain. TB family. Lutfi Rohman often invites people to pray when doing daily activities. Akhmad Nasrullah's family invites that every activity always begins with prayer. TB family. Machfudz, asked the children to pray in every activity.

According to the Zamzam Riyadhi family, by getting used to reading prayers in daily life, children will become accustomed to them when they are adults. Iwan Sofwan's family educates their children from an early age with tahfizh Al-Qur'an, both at home and in day care homes. Khairul Ridwan's family controls their children's prayers every day For the Ferdiansyah family, teaching the practice of daily prayer can be by sticking the prayer on the wall or on the wall. Irman Mukhtar's family did this. On the walls of his house are the daily prayers. Rifqi Firdaus' family, Syafrijal Sabon's family, and Irham Indallah's family used to teach short prayers after their children had read or memorized the Qur'an.

Lutfi Ardiansyah's family memorized together. Lutfi created a fun memorizing atmosphere for his children. Ulfi's family reads prayers when doing daily activities, such as praying before going to bed or praying before eating, and so on The Ganang Pamungkas family uses daily prayers in every activity, so that children can memorize and practice it.

Asep Saepuddi's family used to read prayers when doing their daily activities. Ibrahim Aryadi's family did the same. Irham Indallah's family always invites them to pray when they are about to do something, such as when they purify themselves for prayer. Akhmad Nasrullah's family trains children to pray on time and sunnah.

Asep Saepuddin's family always invites their children to pray congregation and teach charity. Ferdiansyah's family invites their children to pray together, both at the mosque and at home.

Ibrahim Aryadi's family performs the 5 daily prayers, reads the Qur'an, practices obligatory fasting and sunnah fasting, and respects the people in their social circle. Irman Mukhtar's family teaches their children to pray five times a day, recite the Al-Qur'an after sunset, and pray when doing daily activities. Lufti Ardiansyah's family recites the Al-Qur'an with his family members. Congregational prayers were also performed together. The family of Rifki Firdaus did the same thing.

Syafrijal Sabon's family recites the Al-Qur'an, prays in congregation, gives charity, and teaches good words. TB family. Machfudz performs prayers and recites the Al-Qur'an. The Tubagus Lutfi Rohman family performs prayers, ablution, prays, dhikr, and reads the Al-Qur'an. The Ganang Pamungkas family familiarizes their children with congregational prayers. The son (Dzeko) introduces congregational prayers at the mosque and the daughter (Keiza) prays at home with the guidance of her mother. "We also teach noble character to our children," said Ganang.

Zamzam Riyadhi's family invites the children to play. Khairul Ridwan's family trains their children to pray, worship, and behave well. Giving gifts is done by parents when the child's behavior is seen as happy, as was done by Fatih Hudan's family. Those gifts.

Asep Saepudin's family gave gifts to their children to encourage them. Ferdiansyah's family also applies gift giving. The family of Ibrahim Aryadi, family of Irman Mukhtar, family of Lufti Adriansyah, family of $\mathrm{Tb}$. Machfudz, and the family of Tubagus Lutfi Rohman.

Akhmad Nasrullah's family did not apply the gift due to circumstances and conditions. According to Kahirul Ridwan, giving gifts to children, as an appreciation for children's achievements, is of course okay, but it must be the best gift. The families of Ganang Pamungkas and Irham Indallah do not always give gifts to children who memorize the letters of the 
R. Renny Pudjiati et al; Saudi J. Humanities Soc Sci, Jan, 2022; 7(1): 14-20

Qur'an. Iwan Sofwan's family sometimes give gifts to their children, especially for the achievement of memorizing the Qur'an. The Tubagus Lutfi Rohman family observes the daily behavior of their children. If something is not right, it is immediately corrected. Irham Indallah's family controls the children every day. Early childhood development is very significant.

The evaluation was carried out by the Ganang Pamungkas family by always setting an example for the children. However, if there is something wrong with the child's behavior, then the Danang family will discuss it.

Tahfizh Al-Qur'an for early childhood adorns many families in Serang City. So far, there are formal tahfizh Al-Qur'an schools, such as the birth of special schools for tahfizh Al-Qur'an, there are non-formal ones such as in residential areas, some are informal, such as in homes.

The Tahfizh Al-Qur'an in Serang City needs the attention of the Serang City Government, the Serang City Regional Representative Council, Islamic mass organizations, and Islamic religious leaders. Tahfizh AlQur'an is very likely to be a subject in public schools. In fact, it is also possible to be one of the requirements to enter universities in Serang City. This is of course specifically for Muslims. The city of Serang may be the City of Tahfizh Al-Qur'an in Banten Province, given its status as the provincial capital, and has a fairly strong Islamic history since the days of the sultanate.

\section{NOVELTY}

The results of this study indicate that learning tahfizh Al-Qur'an in early childhood is very appropriate to be carried out in family education starting when a mother is pregnant by making the habit of reading and listening to the reading of the Qur'an, this is believed to have a positive effect that significant to children after birth. Children will be more familiar with the sound of lafazh verses of the Qur'an well, so that hearing the sound of reading the Qur'an becomes familiar and easier to memorize. Planning the tahfizh Al-Qur'an program for pregnant women for nine months need to be cultivated regularly, and routinely, until finally memorizing the Qur'an. Parents can continue tahfizh to their children because they already have the provision of tahfizh Al-Qur'an before. The management model for early childhood tahfizh Al-Qur'an learning in family education, based on research results and the level of development of motor, cognitive, emotional, social, linguistic, moral, and religious aspects, can be divided into two classifications, namely for ages 0 years to age 3 years and for ages 3 to 6 years.

\section{CONCLUSIONS AND SUGGESTIONS A. CONCLUSIONS}

The management of learning tahfizh Al-Qur'an in early childhood is divided into two learning tahfizhs.
First, learning tahfizh for children aged 0 years to thr age of 3 years for introduction to Allah SWT through reading and saying the Qur'an. Second, learning from the age of 3 years to the age of 6 years for an introduction to learning to read, write, and memorize the Qur'an.

Tahfizh Al-Qur'an and tahfizh prayers become a learning package for early childhood. The right time to study tahfizh Al-Qur'an is generally after the Maghrib prayer until before the Isha prayer.

\section{B. Suggestions}

Parents are prioritized to have the same vision and goals in managing early childhood education in the family, based on the Al-Quran and Al-Hadith. Parents should be the first and foremost to introduce reading the Qur'an to children from an early age.

Parents must play an active role in guiding, training their children to get used to reading and memorizing the Qur'an at home from an early age before entering formal education. Parents must be patient and consistent in guiding and accompanying learning tahfizh for early childhood children aged 0 years to 3 years and continues to 3-6 years old until adulthood.

The Serang City Government publishes teaching materials and learning methods for tahfizh AlQur'an for early childhood. The Serang City Government together with the Serang City DPRD should support the tahfizh Al-Quran to be institutionalized by issuing regional regulations on $\mathrm{Al}-$ Qur'an education.

The government is trying to carry out the maghrib reciting movement for the family so that the house becomes more fertile with family religious activities.

\section{BIBLIOGRAPHY}

- Abdul, A. (2017). Pengantar Manajemen dan Substansi Administrasi Pendidikan. Buku Pustaka Raja: Jember.

- Abdul, B. (2015). Model Pendidikan Keluarga Dalam Perspektif Al-Qur'an. Mu'adalah: Jurnal Studi Gender dan Anak, 3(1).

- Abdul, H. (2018). Manajemen Pembelajaran Tahfizh Al-Qur'an Pada Pondok Pesantren di Provinsi Lampung. Disertasi. Tidak Diterbitkan. Program Doktor UIN Raden Intan Lampung.

- Abu Ammar dan Abu Fatiah Al-Adnani. (2015). Manfaat-manfaat Menghafal Al-Qur'an: Negerinegeri Penghafal Al-Qur'an. Al-Wafi: Solo.

- $\quad$ Aida, H. (2017). Metode Tahfizh Al-Qur'an Untuk Anak Usia Dini: Kajian Atas Buku Rahasia Sukses 3 Hafizh Quran Cilik Mengguncang Dunia. Jurnal Ilmu-Ilmu Qur'an dan Hadist, 18(1). 
R. Renny Pudjiati et al; Saudi J. Humanities Soc Sci, Jan, 2022; 7(1): 14-20

- Akhyadi A. S dan Mulyono D. (2018). Program Parenting Peran Pendidikan Dalam Meningkatkan Kualitas Pendidikan Keluarga. Abdimas Siliwangi: Jurnal Pengabdian Kepada Mayarakat, 1(1).

- Bahrun, A. M. (2016). Manajemen Pendidikan Islam: Manajemen Orangtua Terhadap Anak. Yin Yang: Jurnal Studi Islam, Gender dan Anak, 11(2).

- Burhanudin, T. R. (2017). Pendidikan Keluarga Dalam Perspektif Al-Quran Surat Al-Tahrim/66 Ayat 6. Metodik Didaktik: Jurnal Pendidikan keSD-an, 12(2).

- Biro Pemerintahan.bantenprov,go,id dan Kesejahteraan Rakyat Provinsi Banten. (2018). diakses hari Senin 15 Maret 2021, pkl. 10.50.

- Chandra A Sofia A dan Giant, F. A. (2017. Gaya Pengasuhan Orangtua pada Anak Usia Dini. Jurnal Pendidikan Anak, 3(2).

- Chusnul, C., Achmad, R., \& dan Titi, P. (2018). The Management of the Tahfizh Al-Qur'an Education Program in Children Tahfizh Yanbu'ul Qur'an Islamic Boarding School Kudus. Educational Management Journal, 7(1).

- Kantor Badan Pusat Statistik (BPS). (2021). Kota Serang, Desember.

- Mulyasa. (2012). Manajemen Pendidikan Karakter,(Bumi Aksara: Jakarta), h. 20.

- Ulwan, A. N. (2015). Pendidikan Anak dalam Islam, (Terjemah: Arif Rahman), Al-Andalus, Sukoharjo.

- Ramayulis. (2008). Ilmu Pendidikan Islam, Kalam Mulia, Jakarta, h. 362

- Sugiyono. (2012). Memahami Penelitian Kualitatif, (Alfabeta:Bandung), h. 131

- Syaeful, R. (2020). Akselarasi Pembelajaran Tahfizh pada Lembaga Pendidikan Al-Qur'an, studi di Pondok Pesantren Wadi Mubarok Bogor, Marwah Indo Media, September, Bogor, (Disertasi: UIN Jakarta, 2020, dalam bentuk Buku).

- Taty, S. (2017). Peningkatan Kecerdasan Moral Anak Melalui Pengunaan Teknik Klarifikasi Nilai (Penelitian Tindakan di RA Nurul Amal Kelompok A Bandung, 2016), Pasca Sarjana Universitas Negeri Jakarta.

- Heni, A. N. (2019). Pengembangan Penyelenggaraan Majelis Ta'lim Di DKI Jakarta ( Studi Kasus Majelis Ta'lim Nurul Hidayah, Majelis
Ta'lim Jam'iyyatul Ummahat, Majelis Ta'lim Raudatun Nisa), Program Studi Doktor Manajemen Pendidikan Islam (MPI) Program Pasca Sarjana Universitas Muhammadiyah Jakarta.

- Muh, M. (2019). Manajemen Perubahan Dalam Perspektif Mutu Lulusan Pesantren (Kajian Pada Pondok Pesantren Attaqwa Putra Bekasi Jawa Barat), Program Studi Doktor Manajemen Pendidikan Islam (MPI) Program Pasca Sarjana Universitas Muhammadiyah Jakarta.

- Abdul, H., \& Fatfiy, A. (2021). "Khashaaishu numuwwi 'th-thifli fiy marhalati 'th-thufuulati $l$ mubakkirah". $\quad$ https://shms-prod.s3 amazonaws.com. Tahmiil: fiy 28 September. Assaa;ah: 17.50 tawqiitu gharbi Indonesia.

- Al-Yasiry, M. N. (2016). "Marhalu 'th-thufuulati 'l-mubakkirati”. http://qu.edu.iq. Tahmiil: fiy 28 September. As-saa'ah: 17.02 tawqiitu gharbi Indonesia.

- Chaidi, I. C. (2021). "ICT in special education. Technium Social Sciences Journal Vol 23, 187 192, September, www.technium science.com.

- Fonseca-Mora, M. C., Machancoses, F. H., Gryb, O., \& Reiterer, S. (2021). Musical aptitude, working memory, general intelligence and plurilingualism: When adults learn to read fluently in a foreign language. Cogent Education, 8(1), 1936371.

- Latif, M., \& Hafid, E. (2021). multicultural attitudes in an Islamic boarding school of South Sulawesi-Indonesia. Cogent Education, 8(1), 1968736.

- Makruf, S. A., \& Intan, P. (2021). The effect of Islamic family education on early childhood's prophetic character. Journal of Early Childhood Care and Education, 4(1), pp. 12-21. http://journal2.uad.ac.id/index.php/jecce/article/vie w/3891.

- UNICEF. (2021). "Tanmiyatu'th-tuhfuulati 'lmubakkirah”. http;//www.unicef.org. Tahmiil: fiy 28 September, As-saa;ah: 16.45 tawqiitu gharbi Indonesia.

- Ulwan, A. N. (2009). Tarbiyatu '-awlaadi fiy 'lislaami. http://www.noor-book.com. Tahmiil : fiy 28 September 2021. As-saa;ah : 17.45 tawqiitu gharbi Indonesia. 